\title{
LEGISLATIVNÍ ÚPRAVA MÍSTNÍHO POPLATKU ZA LÁZEŇSKÝ NEBO REKREAČNÍ POBYT A MÍSTNIIHO POPLATKU Z UBYTOVACÍ KAPACITY V ČESKÉ REPUBLICE
}

\author{
PETR STUDNIČKA
}

\begin{abstract}
Legislative Arrangement of a Local Fee for a Spa or Leisure Stay and a Local Fee for Accommodation in the Czech Republic

Local tax is defined as a pecuniary levy specified by law directed to the municipal budget that can be established or abolished by the local self-government unit, and this unit may also affect local tax in any way in terms of the tax base, the tax rates or any of the correction elements, regardless of whether the taxpayer receives any consideration from the beneficiary, whether this levy is regular or single and of who administers the tax. The catalogue of local taxes in the Czech Republic includes only local fees and real estate tax. The economic autonomy of municipalities as one of the essential characteristics of local self-government is not fulfilled in the Czech Republic in terms of legal regulation. The municipalities do not have sufficient authority to impose local taxes. In the Czech Republic, under Act No. 565/1990 Coll., on local fees, as amended, there are eight different types of local fees. Two local fees have the greatest significance in relation to hospitality, spa and tourism industry. These are the local fee for a spa or leisure stay, which applies to those using accommodation and the local fee for accommodation, which is paid by the accommodation provider. The total annual volume selection of the local fee for accommodation and the local fee for a spa or leisure stay is 515 million CZK, of which the City of Prague falls 245 million CZK, which is $47.5 \%$ of the national selection and thus Prague is the municipality with the highest volume selecting of these local fees in the Czech Republic.
\end{abstract}

Key words: guest, hospitality, local fee, overnight, spa and tourism industry

Klíčová slova: host, hotelnictví, místní poplatek, přenocování, lázeňství a cestovní ruch

DOI: $10.14712 / 23366478.2016 .35$

\section{MÍSTNÍ DANĚ V ČESKÉ REPUBLICE}

Místní daň je zákonem stanovená dávka peněžitého charakteru směřující do rozpočtu obce (kraje), kterou může územní samosprávný celek zavést či zrušit a kterou může rovněž jakýmkoliv způsobem ovlivnit co do daňového základu, sazby daně či některého z korekčních prvků. Do katalogu místních daní lze v podmínkách České republiky zařadit pouze místní poplatky a daň z nemovitých věcí. ${ }^{1}$ Při takto úzkém vymezení místních daní nenacházíme v České republice žádné místní daně na úrovni

1 RADVAN, M.: Mistni daně. Praha, 2012, s. 15. 
krajů jako vyšších územních samosprávných celků. Na rozdíl od místních poplatků není obcím přiznáno právo rozhodovat, zda daň z nemovitých věcí na svém území zavedou, či nikoliv. Mají možnost pouze rozhodovat o zavedení či úpravě koeficientů násobících základní sazbu daně nebo celou daňovou povinnost a mají právo stanovit osvobození pro nemovitosti dotčené živelní pohromou nebo pro vybrané zemědělské pozemky.

Výše místních daní v České republice je vybírána v hodnotě 14,9 mld. Kč ročně (2013) a na celkových daňových př́ijmech se podílí cca 2,2 \%. Mezi nejvýznamnější místní daně v České republice patří místní poplatky $(5,1$ mld. Kč). Na rozdíl od daně z nemovitých věcí $(9,7$ mld. Kč) mají charakter fakultativní, a nikoliv obligatorní. To znamená, že je zcela na úvaze obce, zda a které místní poplatky na svém území zavede. U místních poplatků si obce samy stanovují konkrétní sazbu poplatku, podmínky placení, př́ípadná osvobození a další konstrukční prvky, které nejsou striktně určeny prrímo zákonem o místních poplatcích č. 565/1990 Sb., za podmínky, že nepřekročí zákonné zmocnění. Místní poplatky plní tři základní funkce - jsou paušální úhradou za související služby poskytované obcí, mají povahu místního zdanění nebo plní převážně regulační funkci. Při rozhodování obce, jaký místní poplatek zavést, či nikoliv, převažuje fiskální efekt, nad funkcí regulační a stimulační. ${ }^{2}$

\section{ZÁKON O MÍSTNÍCH POPLATCÍCH Č. 565/1990 SB.}

V České republice jsou na výkonech cestovního ruchu, hotelnictví a lázeňství nejvíce závislé dva místní poplatky na základě zákona č. 565/1990 Sb., o místních poplatcích, ve znění pozdějších předpisủ. Jedná se o místní poplatek za lázeňský nebo rekreační pobyt (§ 3) a místní poplatek z ubytovací kapacity (§ 7).

Novodobá historie místního poplatku za lázeňský nebo rekreační pobyt se datuje od roku $1952^{3}$, kdy byla přijata legislativní úprava místních poplatků v zákonu č. 82/1952 Sb., o místních poplatcích, z něhož dle $\S 2$ odst. 1 platilo, že druhy poplatků, které jsou místní národní výbory povinny vybírat, stanoví vláda a předpisy o těchto poplatcích vydá ministr financí. Lázeňská daň byla na celém území našeho státu dvakrát zrušena. Poprvé od 1. 1. 1952, podruhé od 1. 11. 1960. V tomto období byla předmětná daň od 1. 5. 1957 do 31. 10. 1960 dočasně obnovena. Na základě zákonodárného zmocnění byla vydána ministerstvem financí vyhláška č. 71 ze dne 8. 4. 1964, o lázeňském poplatku, který byl vybírán od všech osob, které přechodně pobývaly v lázeňských místech v období od 1. 5. do 30. 9. (jen pokud byla mimo sezonu v provozu všechna lázeňská zařízení a prováděny služby pro zákazníky, bylo možné vybírat poplatek i v této době, avšak maximálně v poloviční výši) a jeho použití bylo určeno převážně na financování zařízení a služeb sloužících lázeňským hostům. Výtěžek poplatku byl účelově vázán a směl být využit pouze pro udržování a zlepšování lázeňských míst (parků, stezek atd.) a pro reklamu lázní. Tehdy měl místní poplatek striktně fiskální funkci.

2 PLZÁKOVÁ, L. - STUDNIČKA, P. - TITTELBACHOVÁ, Š.: Vliv mistnich poplatků na rozvoj cestovniho ruchu. Praha, 2015, s. 9.

3 BŘEŇ, J.: Místní poplatek za lázeňský nebo rekreační pobyt. Deník veřejné správy [online], [cit. 16. 9. 2014]. Dostupné z: http://denik.obce.cz/clanek.asp?id=6600079. 
Prostřednictvím vyhlášky č. 67/1966 byl zaveden nový poplatek za ubytování v rekreačních oblastech, který se stal jistým ,protějškem“ $\mathrm{k}$ lázeňskému poplatku, čímž nebylo možné tento poplatek zavádět v místech s převažujícími sportovními a rekreačními aktivitami. Poslední právní úprava poplatku za lázeňský nebo rekreační pobyt je spjata s vyhláškou č. 216/1988 Sb., o místním poplatku ze psů a o lázeňském poplatku, která byla účinná od 1.1.1989 do 1. 1. 1991. Tato vyhláška byla velmi podobná stávající úpravě v zákonu o místních poplatcích.

Sazbu místních poplatků a další podrobnosti (splatnost, ohlašovací povinnost, osvobození atp.) stanovují obce $\mathrm{v}$ rámci jejich samostatné působnosti prostřednictvím obecně závazné vyhlášky. Zákon vymezuje některé př́ípady a osoby, které jsou z placení poplatku vyloučeny, a v některých prŕípadech umožňuje obci stanovit vyhláškou nebo dohodou paušální poplatek. Řízení o poplatcích vede obecní úřad v přenesené působnosti. Jednotlivé místní poplatky vybírá $\mathrm{v}$ České republice rozdílný počet obcí (Tabulka 1).

Tabulka 1: Počet obcí a objem místních poplatků v České republice v roce 2013

\begin{tabular}{|l|c|c|c|}
\hline \multicolumn{1}{|c|}{ Místní poplatek } & Počet obcí & Zastoupení v \% & Objem výběru v Kč \\
\hline Ze psů & 6086 & 97,5 & 280647037 \\
\hline Za odpady & 4335 & 69,4 & 3473641300 \\
\hline Za užívání veřejného prostranství & 2710 & 43,4 & 629030561 \\
\hline Z ubytovací kapacity & 1442 & 23,1 & 213139953 \\
\hline Ze vstupného & 936 & 15,0 & 56112018 \\
\hline Za lázeňský nebo rekreační pobyt & 907 & 14,5 & 300677770 \\
\hline Za povolení k vjezdu & 133 & 2,1 & 22364425 \\
\hline Za zhodnocení stavebního pozemku & 53 & 0,8 & 7115200 \\
\hline Celkem & & & 4982728264 \\
\hline
\end{tabular}

Zdroj: Vlastní zpracování s využitím dat Rozpočet obce, $2014 .^{4}$

\section{MÍSTNÍ POPLATEK ZA LÁZEŇSKÝ NEBO REKREAČNÍ POBYT A MÍSTNÍ POPLATEK Z UBYTOVACÍ KAPACITY}

Místní poplatek za lázeňský nebo rekreační pobyt lze vybírat v lázeňských místech a v místech ,soustředěného turistického ruchu“. Pro obec jej vybírá od hostů ubytovatel. Maximální sazba je 15 Kč za osobu a den. Poplatku nepodléhají př́ípady, kdy je prokázán jiný účel ubytování než léčebný nebo rekreační. Od roku 1991 se sazba tohoto poplatku nezměnila. Místní poplatek z ubytovací kapacity se vybírá v zařízeních určených k přechodnému ubytování za úplatu; poplatku jsou zproštěna zařízení zajišt’ující přechodné ubytování studentů a žáků, zdravotnická a lázeňská zařízení (pokud

4 Rozpočet veřejně. 2015. Rozklikávaci rozpočet obce [online], [cit. 20. 10. 2015]. Dostupné z: http://www rozpocetobce.cz. 
neposkytují hotelové služby), sociální a charitativní zařízení. Poplatek platí ubytovatel, maximální výše je 6 Kč za každé využité lůžko a den. Od roku 1991 se jeho výše změnila dvakrát - z 2 nejdř́ive na 4 a nyní na 6 korun (Graf 1).

Graf 1: Změny maximálních sazeb místních poplatků v České republice v letech 1991-2014

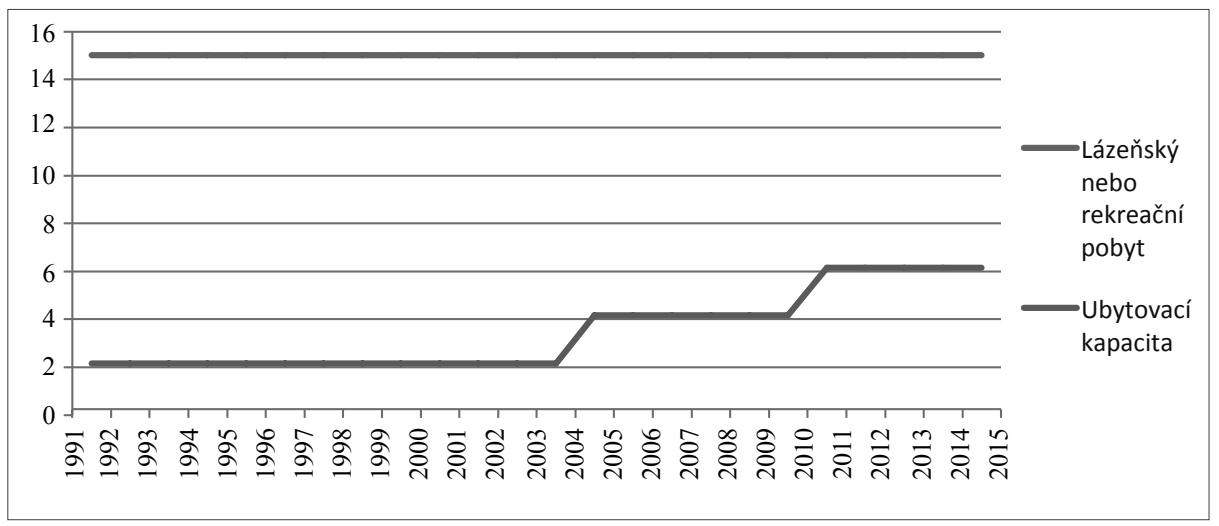

Zdroj: Vlastní zpracování podle zákona č. 565/1990 Sb., 2014..$^{5}$

Od plateb místních poplatků jsou osvobozeny různé, ale z hlediska výkonů individuálních a hromadných ubytovacích zařízení významné skupiny osob (např. děti, senioři, organizované skupiny v rámci služebních cest), resp. zařízení (sociální, charitativní, zdravotnická, lázeňská, školská) a o výběru těchto místních poplatků rozhodují jednotlivé obce vydáním obecně závazných vyhlášek, které schvalují zastupitelstva obcí v rámci své samostatné působnosti. Zákon navíc stanovuje maximální sazbu těchto místních poplatků a je na obcích, zda vůbec a pokud ano, pak v jaké výši je na svém území stanoví. Proto není možná úplná srovnatelnost těchto právních norem.

Z celkového počtu 6242 obcí v České republice vybíralo v roce 2013 místní poplatek za lázeňský nebo rekreační pobyt 907 obcí (14,5 \%) a místní poplatek z ubytovací kapacity 1442 obcí $(23,1 \%)$. U obou místních poplatků má z hlediska objemu peněžních prostředků dominantní postavení hlavní město Praha (Tabulka 2).

V žebříčku třiceti obcí, které vybírají nejvyšší objem místního poplatku za lázeňský nebo rekreační pobyt a místního poplatku z ubytovací kapacity do svých rozpočtů, mají velmi významné postavení destinace lázeňského typu (Karlovy Vary, Mariánské Lázně, Františkovy Lázně, Třeboň, Luhačovice, Jeseník), horské destinace (Špindlerův Mlýn, Pec pod Sněžkou, Harrachov, Velké Karlovice), destinace u vodní plochy (Lipno nad Vltavou, Pasohlávky, Doksy) a destinace kulturně-historického typu (Praha, Český Krumlov). Seznam prvních deseti obcí s nejvyšším objemem výběru obou místních poplatků je uveden v Tabulce 3 .

5 Zákon č. 565/1990 Sb., o místních poplatcích, ve znění pozdějších předpisů. 
Tabulka 2: Objem místních poplatků na území České republiky a v hlavním městě Praze v letech 2000 a 2013 v Kč

\begin{tabular}{|c|c|c|c|c|}
\hline \multirow{2}{*}{ Rok } & \multicolumn{2}{|c|}{ Česká republika } & \multicolumn{2}{c|}{ Hlavní město Praha } \\
\cline { 2 - 5 } & $\begin{array}{c}\text { Lázeňský nebo } \\
\text { rekreační pobyt }\end{array}$ & $\begin{array}{c}\text { Ubytovací } \\
\text { kapacita }\end{array}$ & $\begin{array}{c}\text { Lázeňský nebo } \\
\text { rekreační pobyt }\end{array}$ & $\begin{array}{c}\text { Ubytovací } \\
\text { kapacita }\end{array}$ \\
\hline 2000 & 213990740 & 64762020 & 88803830 & 21701880 \\
\hline 2013 & 306677770 & 213139953 & 138467136 & 107586750 \\
\hline
\end{tabular}

Zdroj: Vlastní zpracování podle Plzáková, Studnička, Tittelbachová, 2015.

Tabulka 3: Deset obcí s nejvyšším objemem výběru místních poplatků v České republice v roce 2013 v Kč

\begin{tabular}{|l|c|l|c|}
\hline \multicolumn{1}{|c|}{ Obec } & $\begin{array}{c}\text { Lázeňský nebo } \\
\text { rekreační pobyt }\end{array}$ & \multicolumn{1}{c|}{ Obec } & Ubytovací kapacita \\
\hline Praha & 138467136 & Praha & 107586750 \\
\hline Karlovy Vary & 23875726 & Karlovy Vary & 6596385 \\
\hline Mariánské Lázně & 12196129 & Brno & 6195914 \\
\hline Špindlerův Mlýn & 8246073 & Plzeň & 5804915 \\
\hline Františkovy Lázně & 4657651 & Špindlerův Mlýn & 4743186 \\
\hline Luhačovice & 4593398 & Mariánské Lázně & 4712141 \\
\hline Lipno nad Vltavou & 4139072 & Pec pod Sněžkou & 1676252 \\
\hline Třeboň & 4003356 & Lipno nad Vltavou & 1556895 \\
\hline Harrachov & 3951659 & Mladá Boleslav & 1466697 \\
\hline Český Krumlov & 3617573 & Český Krumlov & 1457343 \\
\hline
\end{tabular}

Zdroj: Vlastní zpracování podle dat Rozpočet obce, 2014.

Tabulka 4: Roční objem výběru místních poplatků v České republice v letech 2000-2015 v Kč

\begin{tabular}{|c|c|c|}
\hline Rok & Lázeňský nebo rekreační pobyt & Ubytovací kapacita \\
\hline 2000 & 213990740 & 64762020 \\
\hline 2001 & 229942420 & 66243290 \\
\hline 2002 & 218698930 & 65810430 \\
\hline 2003 & 252063900 & 69381930 \\
\hline 2004 & 289383680 & 116481670 \\
\hline 2005 & 296826670 & 131081460 \\
\hline 2006 & 296704400 & 135441940 \\
\hline 2007 & 312211230 & 143565350 \\
\hline 2008 & 309229440 & 146239070 \\
\hline 2009 & 281944650 & 134818200 \\
\hline 2010 & 283848550 & 147333490 \\
\hline
\end{tabular}




\begin{tabular}{|c|c|c|}
\hline 2011 & 301772810 & 166078370 \\
\hline 2012 & 304117770 & 187943430 \\
\hline 2013 & 300677770 & 213139953 \\
\hline 2014 & 304052666 & 223912974 \\
\hline 2015 & 326569583 & 239546279 \\
\hline Celkem & 4522035209 & 2251779856 \\
\hline
\end{tabular}

Zdroj: Vlastní zpracování s využitím dat Rozpočet obce, 2014 a MONITOR, $2016 .^{6}$

Zatímco v roce 2000 byl celkový roční objem výběru obou místních poplatků velmi rozdílný, tempo růstu se u každého z nich vyvíjí odlišně a celkové roční objemy výběru se u obou místních poplatků k sobě postupně přibližují, jak je zřejmé u roku 2015. Tento stav je dán nejen platnou legislativou a počtem obcí, které tyto místní poplatky vybírají, ale i nastavenými maximálními sazbami (Graf 2).

Graf 2: Vývoj ročního objemu výběru místního poplatku za lázeňský nebo rekreační pobyt a místního poplatku z ubytovací kapacity v České republice v letech 2000-2015

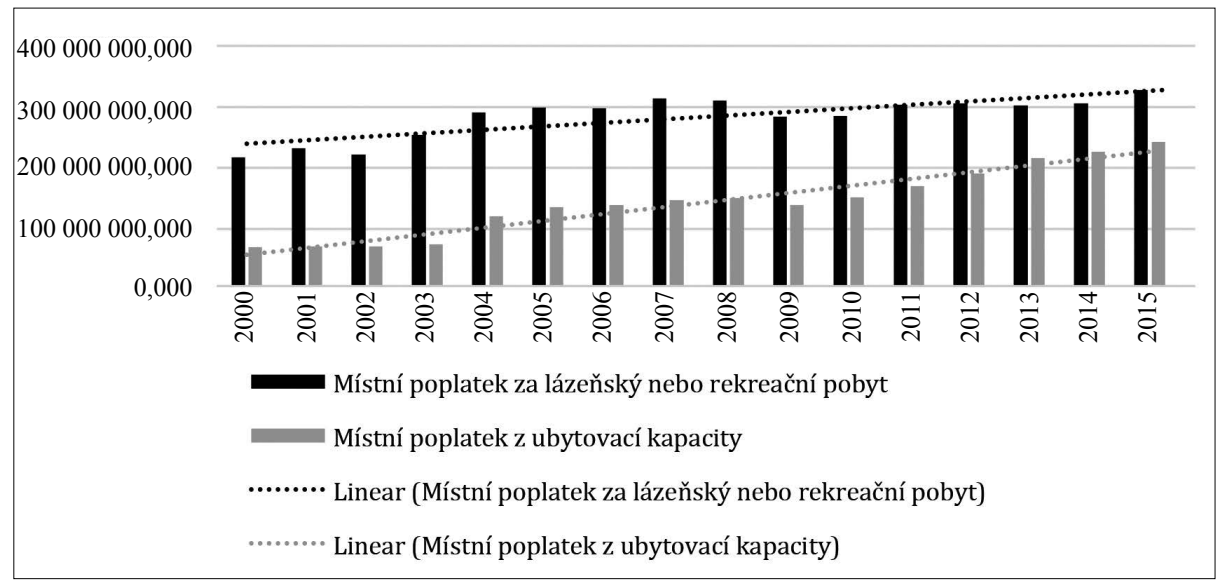

Zdroj: Vlastní zpracování s využitím dat Rozpočet obce, 2014 a MONITOR, 2016.

Poplatkově právní skutečnosti, poplatkové povinnosti a způsoby jejich plnění jsou stanoveny zákonem o místních poplatcích. Tento zákon vymezuje náležitosti poplatkového vztahu poplatkového subjektu a obce pomocí poplatkových prvků. Existují poplatkové prvky obligatorní, nezbytné pro stanovení poplatkových vztahů (např. objekt a subjekt poplatku, sazba poplatku), jsou též poplatkové prvky fakultativní (např. osvobození od poplatku, úlevy na poplatku).

Zákon o místních poplatcích umožňuje některé poplatky paušalovat. Jde o stanovení výše poplatku peněžitou částkou bez bezprostřední vazby na konkrétní poplatko-

6 MONITOR. 2016. Př́rjmy a výdaje územních rozpočtů [online], [cit. 25. 5. 2016]. Dostupné z: http:// monitor.statnipokladna.cz/analyza/\#query=13. 
vě-právní skutečnosti s vazbou např̀. na vymezené časové období (kalendářní časové úseky - týden, měsíc, rok). Paušální částka místního poplatku je částka, která neplyne z konkrétní daňově-právní skutečnosti, nýbrž z jejího předpokladu; sjednává se dopředu, předtím, než konkrétní daňově-právní skutečnost nastane. Poplatek stanovený paušálem je splatný po skončení poplatkového období nebo ukončení poplatkově-právní skutečnosti. U místního poplatku za lázeňský nebo rekreační pobyt lze paušalovat poplatek jednostranným stanovením paušálu (týdenní, měsíční nebo roční částka bez ohledu na počet osob a dnů jejich pobytu v místě). U místního poplatku z ubytovací kapacity lze stanovit paušální poplatek po dohodě s poplatníkem. Paušalování by mělo přispět zejména ke zjednodušení procesu, $\mathrm{v}$ rámci kterého $\mathrm{k}$ realizaci poplatku dochází. ${ }^{7}$ Plnění poplatkových povinností je uvedeno v Tabulce 5.

Tabulka 5: Charakteristika místních poplatků v České republice

\begin{tabular}{|c|c|c|}
\hline $\begin{array}{c}\text { Charakteristika } \\
\text { poplatku }\end{array}$ & Lázeňský nebo rekreační pobyt & Ubytovací kapacita \\
\hline Subjekt & $\begin{array}{l}\text { Poplatník: fyzická osoba } \\
\text { Plátce: ubytovatelé (fyzická nebo } \\
\text { právnická osoba) }\end{array}$ & $\begin{array}{l}\text { Poplatník: ubytovatelé (fyzická } \\
\text { nebo právnická osoba) }\end{array}$ \\
\hline Objekt & $\begin{array}{l}\text { Pobyt konkrétních fyzických osob } \\
\text { ve vybraných místech }\end{array}$ & Využitá lůžková kapacita \\
\hline $\begin{array}{l}\text { Poplatkový } \\
\text { základ }\end{array}$ & $\begin{array}{l}\text { Přechodná prŕítomnost ve } \\
\text { vybraných místech za účelem } \\
\text { lázeňského či rekreačního pobytu } \\
\text { (počet dní pobytu) }\end{array}$ & $\begin{array}{l}\text { Využitá ubytovací kapacita ve } \\
\text { vybraných místech (obsazenost } \\
\text { lůžek) }\end{array}$ \\
\hline Sazba & Až $15 \mathrm{Kč} /$ osoba/den & Až 6 Kč/lůžko/den \\
\hline Paušalování & $\begin{array}{l}\text { Týdenní, měsíční nebo roční } \\
\text { paušální částka - bez alternativy }\end{array}$ & $\begin{array}{l}\text { Roční paušální částka - po } \\
\text { akceptaci poplatníkem }\end{array}$ \\
\hline $\begin{array}{l}\text { Místní příslušnost } \\
\text { k vyměření }\end{array}$ & $\begin{array}{l}\text { Obec, na jejímž území je } \\
\text { přechodné ubytování poskytnuto }\end{array}$ & $\begin{array}{l}\text { Obec, na jejímž území je ubytování } \\
\text { poskytnuto }\end{array}$ \\
\hline $\begin{array}{l}\text { Poplatkové } \\
\text { období }\end{array}$ & $\begin{array}{l}\text { Nemá poplatkové období; poplatek } \\
\text { se váže na každý započatý den } \\
\text { pobytu (kromě dne příchodu), } \\
\text { v prrípadě paušalování týden, měsíc } \\
\text { nebo rok }\end{array}$ & $\begin{array}{l}\text { Nemá poplatkové období; poplatek } \\
\text { se váže na každé využité lůžko } \\
\text { a den, v případě paušalování } \\
\text { rok (období } 12 \text { po sobě jdoucích } \\
\text { kalendářních měsíců) }\end{array}$ \\
\hline $\begin{array}{l}\text { Vyjmutí } \\
\text { z poplatkové } \\
\text { povinnosti }\end{array}$ & $\begin{array}{l}\text { Poplatku nepodléhají osoby } \\
\text { nevidomé, bezmocné a osoby } \\
\text { s těžkým zdravotním postižením, } \\
\text { kterým byl přiznán III. stupeň } \\
\text { mimořádných výhod, a jejich } \\
\text { průvodci, osoby mladší } 18 \text { let } \\
\text { a starší } 70 \text { let nebo osoby, na které } \\
\text { náležejí přídavky na děti }\end{array}$ & $\begin{array}{l}\text { Poplatku nepodléhá ubytovací } \\
\text { kapacita v zařízeních sloužících } \\
\text { pro přechodné ubytování studentů } \\
\text { a žáků, ubytovací kapacita ve } \\
\text { zdravotnických nebo lázeňských } \\
\text { zařízeních, pokud nejsou užívána } \\
\text { jako hotelová zařízení, ubytovací } \\
\text { kapacita v zařízeních sloužících } \\
\text { sociálním a charitativním účelům }\end{array}$ \\
\hline
\end{tabular}

7 PELC, V.: Mistni poplatky - praktická př́ručka pro obce. 2. vyd. Praha, 2012, s. 1-17. 


\begin{tabular}{|l|l|l|}
\hline $\begin{array}{l}\text { Osvobození } \\
\text { od poplatkové } \\
\text { povinnosti }\end{array}$ & Není & Není \\
\hline $\begin{array}{l}\text { Nepeněžité } \\
\text { povinnosti } \\
\text { poplatkových } \\
\text { subjektů }\end{array}$ & $\begin{array}{l}\text { Ubytovatel je povinen vést } \\
\text { v písemné podobě evidenční } \\
\text { knihu, zápisy musí být uspořádány } \\
\text { postupně z časového hlediska; } \\
\text { kniha se uchovává po dobu 6 let od } \\
\text { provedení posledního zápisu }\end{array}$ & $\begin{array}{l}\text { Ubytovatel je povinen vést } \\
\text { evidenční knihu }\end{array}$ \\
\hline
\end{tabular}

Zdroj: Vlastní zpracování podle Pelc, 2012.

Změny poplatkových prvků u obou místních poplatků z hlediska jejich legislativní úpravy v období od 1. 1. 1991 do 31. 10. 2015 jsou uvedeny v Tabulce 6 (místní poplatek za lázeňský nebo rekreační pobyt) a v Tabulce 7 (místní poplatek z ubytovací kapacity).

Tabulka 6: Legislativní změny - místní poplatek za lázeňský nebo rekreační pobyt

\begin{tabular}{|c|c|c|}
\hline $\begin{array}{l}\text { Termín } \\
\text { Zákon }\end{array}$ & Kategorie & Charakteristika \\
\hline $\begin{array}{l}\text { 1. } 1.1991 \\
556 / 1990 \mathrm{Sb} \text {. }\end{array}$ & $\begin{array}{l}\text { Poplatník } \\
\text { Plátce } \\
\text { Vyjmutí } \\
\text { z poplatkové } \\
\text { povinnosti }\end{array}$ & $\begin{array}{l}\text { Poplatek platí fyzické osoby, které přechodně a za } \\
\text { úplatu pobývají v lázeňských místech a v místech } \\
\text { soustředěného turistického ruchu za účelem léčení nebo } \\
\text { rekreace. } \\
\text { Poplatek vybírá pro obec fyzická nebo právnická osoba, } \\
\text { která přechodné ubytování poskytla; tato osoba za } \\
\text { poplatek ručí. } \\
\text { Osoby nevidomé, bezmocné a držitelé průkazů ZTP/P } \\
\text { a jejich průvodci, osoby nemocné, kterým byla lázeňská } \\
\text { péče poskytnuta v rámci pracovní neschopnosti, osoby, } \\
\text { kterým byl poskytnut rekondiční pobyt, osoby mladší } \\
18 \text { let a starší } 70 \text { let nebo osoby, na které náležejí } \\
\text { př́idavky na dítě, anebo vojáci v základní službě a osoby, } \\
\text { které vykonávají civilní službu. } \\
\text { Až } 15 \text { Kč/osoba/den, popř. stanovený paušál, který } \\
\text { může obec po dohodě s poplatníkem stanovit také roční } \\
\text { paušální částkou. }\end{array}$ \\
\hline $\begin{array}{l}\text { 1. } 1.2004 \\
229 / 2003 \mathrm{Sb} .\end{array}$ & $\begin{array}{l}\text { Poplatník } \\
\text { Plátce } \\
\text { Vyjmutí } \\
\text { z poplatkové } \\
\text { povinnosti }\end{array}$ & $\begin{array}{l}\text { Poplatek platí fyzické osoby, které přechodně a za } \\
\text { úplatu pobývají v lázeňských místech a v místech } \\
\text { soustředěného turistického ruchu za účelem léčení nebo } \\
\text { rekreace. } \\
\text { Poplatek vybírá pro obec fyzická nebo právnická osoba, } \\
\text { která přechodné ubytování poskytla; tato osoba za } \\
\text { poplatek ručí. } \\
\text { Osoby nevidomé, bezmocné a držitelé průkazů ZTP/P } \\
\text { a jejich průvodci, osoby nemocné, kterým byla lázeňská } \\
\text { péče poskytnuta v rámci pracovní neschopnosti, osoby, }\end{array}$ \\
\hline
\end{tabular}




\begin{tabular}{|c|c|c|}
\hline $\begin{array}{l}\text { 1. } 1.2004 \\
229 / 2003 \mathrm{Sb} .\end{array}$ & Sazba & $\begin{array}{l}\text { kterým byl poskytnut rekondiční pobyt, osoby mladší } \\
18 \text { let a starší } 70 \text { let nebo osoby, na které náležejí } \\
\text { přídavky na dítě, anebo vojáci v základní službě a osoby, } \\
\text { které vykonávají civilní službu. } \\
\text { Až } 15 \text { Kč/osoba/den pobytu, není-li tento dnem } \\
\text { prríchodu, popř. stanovený paušál, který mǔže obec po } \\
\text { dohodě s poplatníkem stanovit také týdenní, měsíční } \\
\text { nebo roční paušální částkou. }\end{array}$ \\
\hline $\begin{array}{l}\text { 1. 1. } 2011 \\
281 / 2009 \mathrm{Sb} .\end{array}$ & $\begin{array}{l}\text { Plátce } \\
\text { Vyjmutí } \\
\text { z poplatkové } \\
\text { povinnosti }\end{array}$ & $\begin{array}{l}\text { Poplatek platí fyzické osoby, které přechodně a za } \\
\text { úplatu pobývají v lázeňských místech a v místech } \\
\text { soustředěného turistického ruchu za účelem léčení nebo } \\
\text { rekreace. } \\
\text { Poplatek vybírá pro obec fyzická nebo právnická osoba, } \\
\text { která přechodné ubytování poskytla; tato osoba za } \\
\text { poplatek ručí. } \\
\text { Osoby nevidomé, bezmocné a držitelé průkazů ZTP/P } \\
\text { a jejich průvodci, osoby nemocné, kterým byla lázeňská } \\
\text { péče poskytnuta v rámci pracovní neschopnosti, osoby, } \\
\text { kterým byl poskytnut rekondiční pobyt, osoby mladší } \\
18 \text { let a starší } 70 \text { let nebo osoby, na které náležejí } \\
\text { př́idavky na dítě, anebo vojáci v základní službě a osoby, } \\
\text { které vykonávají civilní službu. } \\
\text { Až } 15 \text { Kč/osoba/den pobytu, není-li tento dnem } \\
\text { prríchodu, popř. stanovený paušál, který může obec po } \\
\text { dohodě s poplatníkem stanovit také týdenní, měsíční } \\
\text { nebo roční paušální částkou. }\end{array}$ \\
\hline
\end{tabular}

Zdroj: Vlastní zpracování podle Pelc, 2012.

Tabulka 7: Legislativní změny - místní poplatek z ubytovací kapacity

\begin{tabular}{|l|l|l|}
\hline $\begin{array}{l}\text { Termín } \\
\text { Zákon }\end{array}$ & Kategorie & Charakteristika \\
\hline $\begin{array}{l}\text { 1.1.1991 } 556 / 1990 \mathrm{Sb} . \\
\text { P8/1994 Sb. }\end{array}$ & Předmět & $\begin{array}{l}\text { Poplatek se platí z ubytovací kapacity v rekreačních } \\
\text { a vzdělávacích zařízeních. } \\
\text { Právnické osoby vlastnící zařízení (nebo mající právo } \\
\text { hospodaření) a fyzické osoby, které podnikají (fyzické } \\
\text { osoby poplatek neplatí, pokud platí poplatek dislokační). } \\
\text { Až 2 Kč/lǔžko/den bez ohledu na jeho využití. }\end{array}$ \\
\hline $\begin{array}{l}\text { 1. 7.1994 } \\
\text { Sazba }\end{array}$ & $\begin{array}{l}\text { Poplatek se vybírá v lázeňských místech nebo místech } \\
\text { soustředěného turistického ruchu z ubytovací kapacity } \\
\text { v zařízeních sloužících nebo určených k přechodnému } \\
\text { ubytování za úplatu. } \\
\text { Vyjmuty jsou ubytovací kapacity v zařízeních sloužících } \\
\text { pro přechodné ubytování studentů a žáků, pro ubytování } \\
\text { pracovníků fyzických a právnických osob, které tato } \\
\text { zařízení vlastní nebo k nim mají právo hospodaření, ve } \\
\text { zdravotnických nebo lázeňských zařízeních, pokud }\end{array}$ \\
\hline
\end{tabular}




\begin{tabular}{|c|c|c|}
\hline & $\begin{array}{l}\text { Poplatník } \\
\text { Sazba }\end{array}$ & $\begin{array}{l}\text { nejsou užívána jako hotelová zařizení, v zařízeních } \\
\text { sloužících sociálním a charitativním účelům. } \\
\text { Fyzické a právnické osoby, které zařízení vlastní nebo } \\
\text { právnické osoby s právem hospodaření. } \\
\text { Až } 2 \text { Kč/využité lůžko/den, obec může po dohodě } \\
\text { s poplatníkem stanovit poplatek roční paušální částkou. }\end{array}$ \\
\hline $\begin{array}{l}\text { 1. } 1.2004 \\
229 / 2003 \mathrm{Sb} \text {. }\end{array}$ & $\begin{array}{l}\text { Poplatník } \\
\text { Sazba }\end{array}$ & $\begin{array}{l}\text { Poplatek se vybírá v lázeňských místech nebo místech } \\
\text { soustředěného turistického ruchu z ubytovací kapacity } \\
\text { v zařízeních sloužících nebo určených k přechodnému } \\
\text { ubytování za úplatu. } \\
\text { Ubytovatel (fyzická nebo právnická osoba), který } \\
\text { přechodné ubytování poskytl. } \\
\text { Až } 4 \text { Kč/využité lǔžko/den obec může po dohodě } \\
\text { s poplatníkem stanovit poplatek roční paušální částkou. }\end{array}$ \\
\hline $\begin{array}{l}\text { 1. } 1.2010 \\
348 / 2009 \mathrm{Sb} .\end{array}$ & $\begin{array}{l}\text { Předmět } \\
\text { Vyjmutí } \\
\text { z poplatkové } \\
\text { povinnosti }\end{array}$ & $\begin{array}{l}\text { Poplatek se vybírá v obcích a městech v zařízeních } \\
\text { určených k přechodnému ubytování za úplatu. } \\
\text { Vyjmuty jsou ubytovací kapacity v zařízeních } \\
\text { sloužících pro přechodné ubytování studentů a žáků, } \\
\text { ve zdravotnických nebo lázeňských zařízeních, pokud } \\
\text { nejsou užívána jako hotelová zařízení, v zařízeních } \\
\text { sloužících sociálním a charitativním účelům. } \\
\text { Fyzické a právnické osoby, které přechodné ubytovány } \\
\text { poskytly. } \\
\text { Až } 6 \text { Kč/využité lůžko/den, obec může po dohodě } \\
\text { s poplatníkem stanovit poplatek roční paušální částkou. }\end{array}$ \\
\hline
\end{tabular}

Zdroj: Vlastní zpracování podle Pelc, 2012.

\section{ZÁVĚR}

S ohledem na mnoho shodných konstrukčních prvků u obou místních poplatků lze doporučit jejich sloučení do jednoho místního poplatku. Poplatníkem by měl být ubytovaný (v odborné terminologii turista, resp. host), nebot' právě on nejvíce těží ze služeb, které mu obec jako turistovi poskytuje. Zůstala by tedy zachována charakteristika přechodné doby a úplatnosti. Naopak přechodné a úplatné ubytování v bytových a v rodinných domech a ve stavbách pro rodinnou rekreaci by zpoplatnění nepodléhalo s ohledem na obtížnou dohledatelnost poplatníků a rovněž na fakt, že tyto osoby obvykle nejsou turisty, ale např. studenty ubytovanými na privátech, osobami v pronajatých domech a bytech apod.

Místní poplatek by měl být vybírán v každé obci, nikoliv jen v lázeňských místech a turistických centrech (odstranit ze zákona definici místa soustředěného turistického ruchu); o zavedení poplatku by rozhodovalo výhradně zastupitelstvo obce přijetím, či nepřijetím obecně závazné vyhlášky.

Osvobození by mělo být osobní, vázané na osobu poplatníka. Zákon by měl upravovat pouze základní typy osvobození, větší prostor by měly mít obce jako beneficiáři 
poplatku. Samozřejmostí je osvobození osob nevidomých, závislých na pomoci jiné osoby a osob s těžkým zdravotním postižením. Vhodné se jeví osvobození studentů a žáků ubytovaných $\mathrm{v}$ zařízeních sloužících pro ubytování těchto osob nebo osvobození osob ubytovaných $\mathrm{v}$ zařízeních sloužících sociálním a charitativním účelům. Naopak nelze doporučit osvobození závislé na věku poplatníka (dnes osoby mladší 18 let a starší 70 let věku), nebot' i tyto osoby využívají služeb v obci.

Ubytovatel by měl mít postavení plátce místního poplatku, tedy i nadále by vybíral poplatek vedle ceny za ubytování. Měl by povinnost vést evidenční knihu, avšak bez povinnosti zapisovat účel pobytu, který by nebyl pro placení poplatku rozhodující. Tím by došlo i k rozšíření soukromí ubytovaných.

Obec by si konkrétní sazbu poplatku stanovila v obecně závazné vyhlášce. Není třeba se bránit razantnějšímu navýšení sazby oproti stávajícímu stavu, nebot' poplatek je politicky i ekonomicky neutrální: neplatí jej voliči, ale turisté, kteř́ se obvykle nezajímají o výši místního poplatku a cíl své dovolené si vybírají podle jiných kritérií.

V současné době probíhá diskuse mezi Ministerstvem pro místní rozvoj ČR, obcemi, poskytovateli ubytovacích služeb, akademickou půdou (Vysoká škola hotelová v Praze) a profesními asociacemi (např. Asociace hotelů a restaurací ČR, Asociace horských stř̌edisek ČR, Svaz obchodu a cestovního ruchu ČR) o možné legislativní úpravě zákona č. 565/1990 Sb., týkající se dvou zkoumaných místních poplatků. Mezi uvažované legislativní úpravy patří rozšsiření možnosti uplatňování paušálů, redukce počtu výjimek týkajících se osob a zařízení osvobozených od plateb poplatků, redefinice pojmu ubytovací zařízení, vypuštění definice „místo soustředěného turistického ruchu“, změna maximálních sazeb místních poplatků či jejich účelová vázanost.

Ing. Petr Studnička, PhD.

Vysoká škola hotelová v Praze

studnicka@vsh.cz 